\title{
Media Waves and Moral Panicking: The case of the FIFA World Cup 2010
}

\section{Monique Emser and Suzanne Francis}

\section{Introduction}

In the run-up to the FIFA World Cup in South Africa, human trafficking made headline news in 27 South African newspapers. This resulted in a series of news waves pertaining to perceptions of forced prostitution and child trafficking to come during the World Cup. Evocative headlines capitalising on societal fears appeared in the local media. Out of 350 articles covering human trafficking in South African newspapers between 2006 and 2010, 82 (or 24 per cent) directly linked this sporting event with human trafficking. A sample of headlines included: "Flesh trade fear for World Cup" (Citizen 2006); "Human trafficking casts shadow over 2010" (Sunday Independent 2007); "Human trafficking may escalate ahead of 2010 World Cup - report" (The Weekender 2008); "Warning on child trafficking in 2010" (Cape Argus 2008); "2010 exploitation: Human traffickers ready for World Cup" (Daily News 2009); "Human trafficking red alert: Women, children under threat as World Cup sees prostitution demand rocket" (Daily News 2010).

As with previous international sporting events, the threat of human trafficking quickly became part of public consciousness. Advocacy organisations, such as Molo Songololo, Justice Acts, Not for Sale, Doctors for Life, STOP (Stop Trafficking of People) ${ }^{1)}$ and politicians ${ }^{2)}$ publicly repeated inflated estimates of numbers of women and children who would be trafficked, brutalised and forced into a life of sexual servitude in order to meet the demands of hordes of "sexually deviant, inebriated football fans". It was erroneously portrayed that large sporting events - particularly football - attracted and facilitated the demand and supply of illicit sex. Based on the myth of 40000 sex slaves who were imported from Eastern Europe into Germany, a resultant media hype and moral panic, became part of the South African World Cup discourse. We claim 
that media hypes based on constructed moral panics might be recycled in similar scenarios demonstrating the staying power of such media hypes and the utility of moral panics. As Vasterman (2005: 517) claims:

[M]edia coverage can be a self-fulfilling prophecy. A situation becomes a real crisis because it is described as a crisis; a condition becomes an important social problem because it is described in terms of a sudden deterioration of the situation. In this way media-hype can create new realities, independent from other non-mediated realities.

\section{The dark side of sex, football and South Africa}

Up until 2008, South Africa was ranked as a Tier 2 (Watch List) country for the fourth consecutive year by the United States (US) TIP Report for failing to "comply with the minimum standards for the elimination of trafficking" (UNHCR 2008). According to the report, the government failed to provide adequate data on trafficking (cases investigated and/or prosecuted), and deported and/or prosecute suspected victims without providing appropriate protective services (UNHCR 2008). Although South Africa was taken off the watch list in 2009, the report noted that it still did not comply with the minimum standards. This assessment remained the same in the 2010 report. To date, formulation and harmonisation of legislation in accordance with the prescripts of the Protocol have yet to be fulfilled. The 2010 TIP Report, identified South Africa as "a source, transit, and destination country for men, women, and children subjected to trafficking in persons, specifically forced labour and forced commercial sexual exploitation" (US Department of State 2010). An exploratory study by the Human Sciences Research Council (HSRC) released in March 2010 on the dimensions of human trafficking in southern Africa supported the findings of previous studies that suggested South Africa is a key destination and, to a lesser extent, a country of origin and transit for people trafficked to and from Africa, globally, and internally (HSRC 2010). However, the HSRC study also suffers from methodological weaknesses. Many assumptions and findings are

based on previous studies, without analysing the integrity of the methods and data sets from which they are comprised and it fails to provide empirical evidence 
about trafficking. As such the phenomenon remains conceptually nebulous - an addendum to the superimposed international discourse. The study does note that, "while varying (and often alarmist) statistics pertaining to human trafficking are sometimes reported in the media and by civil society institutions, reliable information on the scale, direction and nature of trafficking remains sparse" (HSRC 2010: iii). However, this cautionary note is often ignored by advocacy organisations and the media, leading to sensationalised accounts that are intended to elicit the attention of politicians. ${ }^{3)}$ Such an approach trivialises complex issues and the experiences of the victims. In one such article a formulaic account of child trafficking was reiterated in its most disturbing form:

Trafficking of children, aged from as young as five to teens, across South African borders is expected to increase sharply. Traffickers are cruel enough to lure children away from poverty-stricken parents, leading these parents to believe that the children will have better education and job opportunities in South Africa. Children from rural South Africa are often 'recruited' or even bought from their parents and moved to the cities. Unfortunately the sad truth is that these children will be beaten, raped and forced into drug addiction, before they are used as prostitutes for sex tourists and paedophiles. But disoriented and far from home, these children become slaves and prisoners of traffickers, and seldom, if ever, find their way home. (Servamus 2010: 24)

\section{The media discourse on human trafficking}

We selected and analysed a total of 91 articles appearing in 27 different South African newspapers. Selection was restricted to the period 2006-2010. Our search criteria were the linkage between human trafficking and the 2010 World Cup. Articles were examined manually and replicated stories were removed, leaving 82 articles. Figure 1 shows the frequency of news articles on human trafficking.

As Figure 1 demonstrates, the majority appeared between 2008 and 2010. The greatest surge was from November to December 2008, followed by May to June 2010 just prior to the World Cup. Two factors influenced the upsurge in November to December 2008. First, a report 


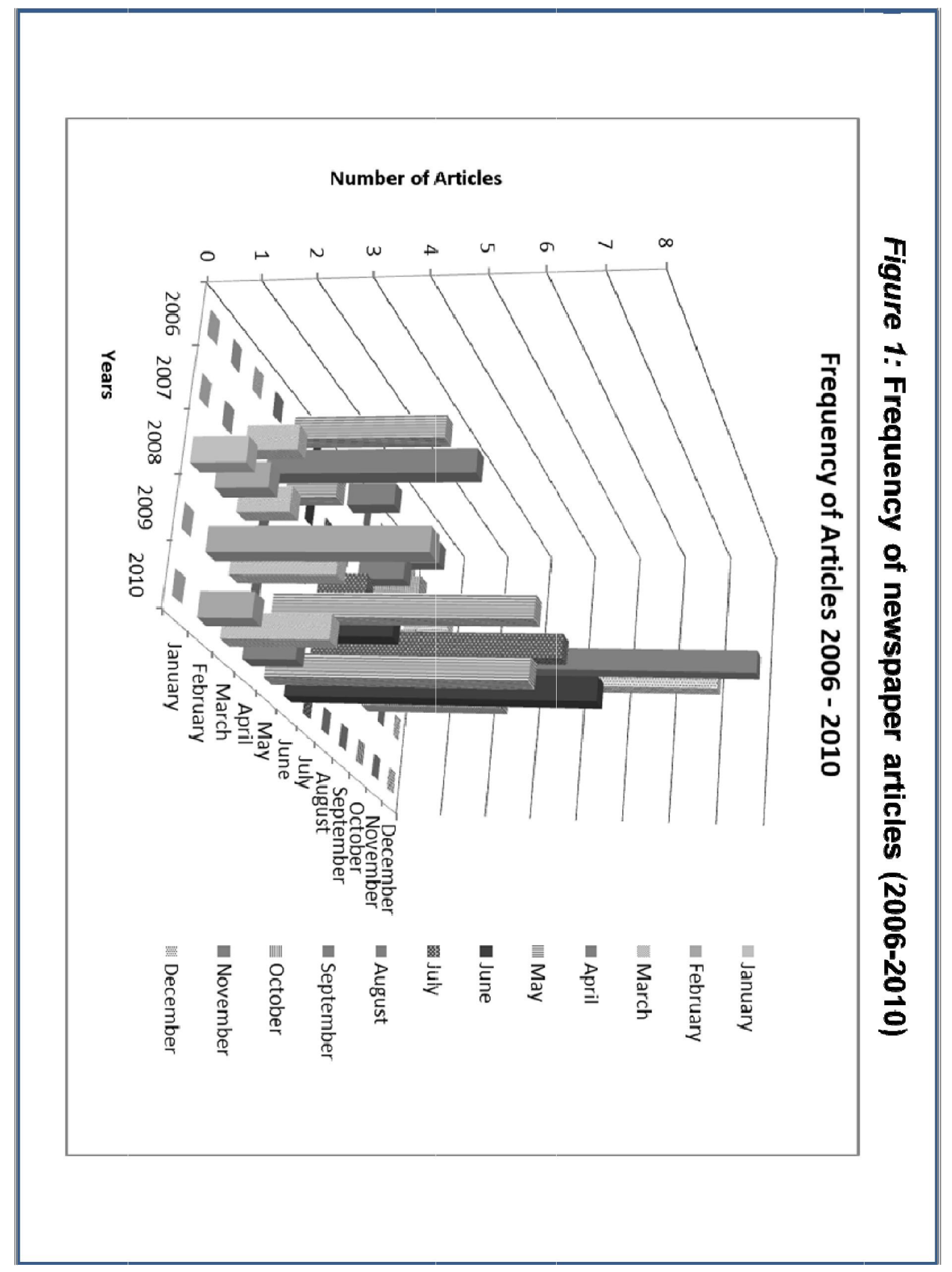


released by the International Organisation for Migration (IOM) on internal trafficking in South Africa identified vulnerable groups and 'hotspots' in the country generated follow-up stories linked to cases of human trafficking. Second, the arrest of a drug and human trafficking 'kingpin' in Port Elizabeth spurred further stories. In the months up to the 2010 World Cup, the media hype on human trafficking adopted the international narrative of the phenomena. Yet, immediately after the World Cup and in the months that followed there was a sharp decline in the number of articles. This is indicative of a lack of evidence that human trafficking did indeed pose a major threat since claims after the fact would have required some evidentiary support.

Figure 2 shows the specific sub-themes of media reports on human trafficking in general.

We examined a total of 350 articles, using the search phrase 'human trafficking' as the basis for selection over the period 2006-2010. We identified reoccurring subthemes in each article which framed human trafficking in different ways. Many of the 350 articles reviewed contained multiple subthemes. These comprised warnings on human trafficking (8); awareness raising campaigns (19); human trafficking and the World Cup (82); children and human trafficking particularly child trafficking, child abduction and kidnapping (96); prostitution and human trafficking (117); calls for legislation (41); labour trafficking and organised begging (8); and 'Nigerian' syndicates as the perpetrators of this crime (15). As Figure 2 demonstrates, the predominant media frame in relation to human trafficking is that of sex-trafficking/(forced) prostitution, and to a large extent child trafficking. These two frames were invariably linked with the 2010 World Cup in 23.4 per cent of articles published during this period. A scan of the stories collapses the complexities of human trafficking into one predominant category - sex trafficking/forced prostitution, with a particular focus on child sex trafficking and prostitution. A sample of newspaper articles which appeared over this timeframe read: "100 000 people could be trafficked into country for 2010" (Cape Times, 6/11/2009). This reiterated the notion that that "large events such as the World Cup created 'booming' markets for prostitution and human trafficking". This was based on a claim by Hanlie Linde, Director of Community Services for the Stellenbosch Municipality and representative of an antitrafficking advocacy organisation - Stop the Trafficking of People - that 100 000 people could be trafficked into South Africa.

Another, "Child trafficking expected to soar in final holiday before 


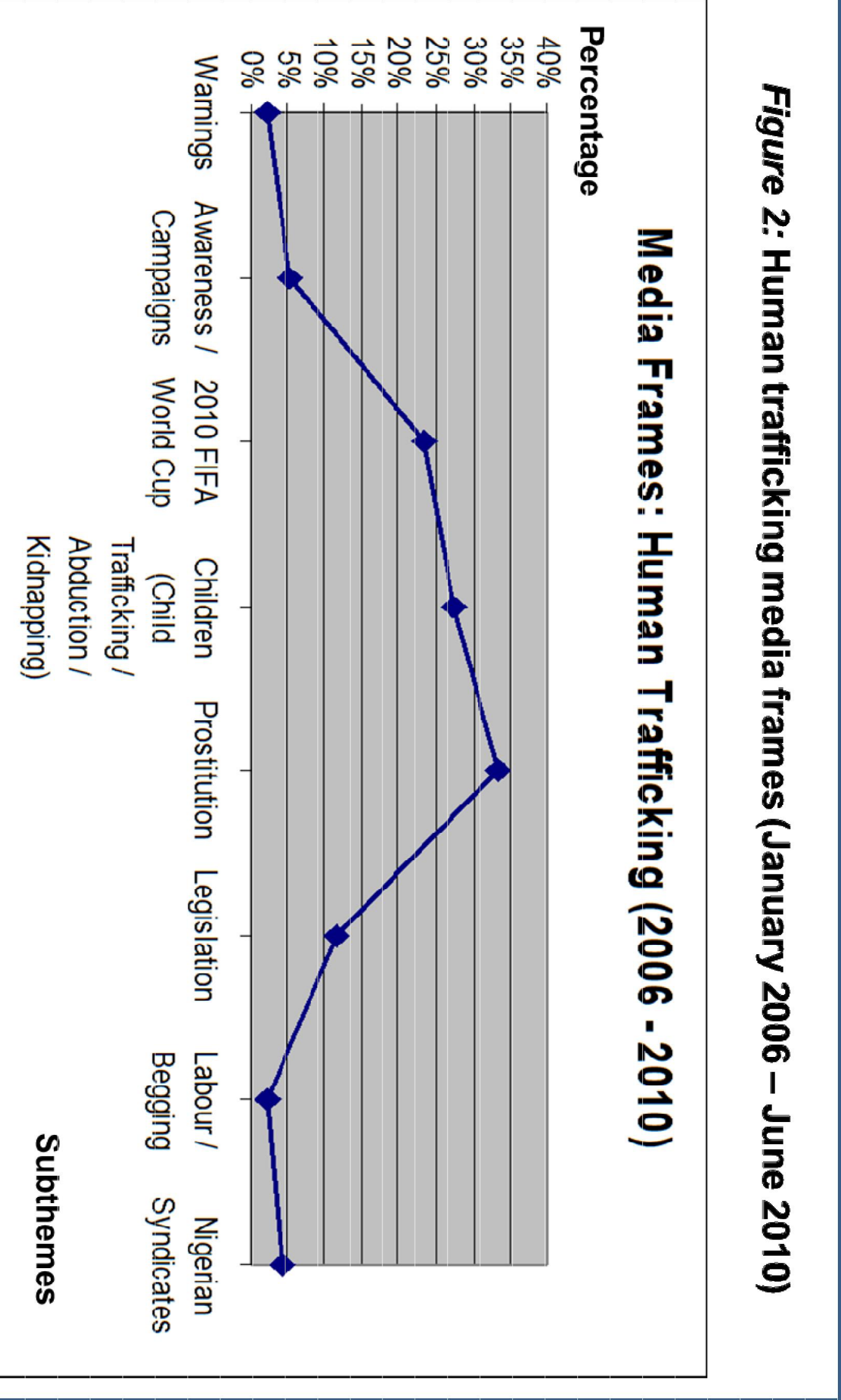


the World Cup. High Alert: Experts call for exceptional vigilance as syndicates hunt for kids to prostitute" (Weekend Post, 3/4/2010) lacks methodological rigor. A victim trauma counsellor is reported in an authoritative manner that "it had been estimated by the International Organisation for Migration (IOM) that more than 40000 women were trafficked in Germany during the last World Cup". ${ }^{4)}$ Hence, "could be trafficked" is now reported as "was trafficked". In addition, street children were collapsed into the category of children trafficked. These methodological problems are at the root of the discourse on human trafficking. The claims made then form the basis for further articles which shape and promote a flawed overall discourse.

Another reads, "Beware of 2010 'sex tourists': Warning on child abuse" (Sowetan, 26/10/2009). This article conflates child trafficking with child sex tourism and paedophilia. Whilst both are repugnant - they are not in every instance child trafficking. Nor, is child prostitution always synonymous with child trafficking. The sad reality is that many child prostitutes (that is, minors under 18 years of age) engage in survival prostitution.

Doctors for Life reported that "approximately 40000 women and children were trafficked into Germany for the previous World Cup for sexual exploitation" (Daily Dispatch, 24/5/2010). However, it is questionable why such assertions were assigned to the South African context, as no substantive data as to the scope of the phenomenon exists. This specious estimate resulted in a number of hoax emails reporting the near-abduction of children from their schools, or of foreign men photographing children outside schools. ${ }^{5)}$ Such hoax emails about child trafficking became so wide-spread that the South African Police Service (SAPS) had to debunk such claims (Barbeau 2010). However, the effect of such emails was a general sense of anxiety amongst parents, teachers' organisations and Childline. As the World Cup was taking place during the mid-year school holidays, it was feared many (unsupervised) children attracted to the football stadiums and fan parks would fall prey to paedophiles and child traffickers (Bowman 2010; Evans 2010; Langanparsad 2010; Pillay 2010; Stander \& Jager 2010).

The concern regarding the wave of sex slaves into South Africa ahead of the 2010 World Cup was first vocalised in 2007.6) Intergovernmental organisations $^{7)}$ (at a joint press conference) raised concerns about the threat of an increase in human trafficking due to a lack of anti-trafficking legislation throughout the Southern African Development Com- 
munity (SADC) region (Molo Songololo 2008: 34). The IOM attributes the 2006 World Cup as serving as "a catalyst for concern over potential increases in trafficking during future major events" (Hennig, et al 2006: 17). The rapid assessment report on the 2010 World Cup indicated two ways in which international sporting events could lead to an increase in human trafficking: (i) they may contribute to a short-term increase in perceived demand for prostitution and other forms of sexual exploitation; (ii) they may facilitate the entry and transit of trafficked persons as 'visitors' due to relaxed visa requirements (Hennig, et al 2006: 17). Melanie O'Connor, Co-ordinator of the Counter Trafficking in Persons Desk, shared these concerns that the 2010 World Cup would allow for "abusers, exploiters and traffickers to meet the perceived increased demand for cheap labour and sexual services" (South African Catholic Bishops Conference 2010).

Such assertions are imbued with symbolic connotations about morality and structured by an international discourse. Unsubstantiated fears related to the sanctity of the state as a provider of core political goods - such as the security of its citizens, and protection of its borders, are advanced. An international discourse that structures the way in which human trafficking is defined and addressed is superimposed onto the domestic context. The South African government responded by formulating security plans with Interpol. As a result, there was an increase in the visibility of police officers, ${ }^{8)}$ both South African and international, deployed for the event. The South African National Defence Force (SANDF) provided patrols along South Africa's $5000 \mathrm{~km}$ porous land border. However, it is a dubious assertion to claim that the methods of raising awareness and the counter-trafficking initiatives can be credited for preventing any influx of the 40000 forced prostitutes since they were a fiction. ${ }^{9)}$ As with the 2006 World Cup, South Africa witnessed neither an influx of prostitutes nor an increase in the victims of trafficking. In fact, in line with the 2006 World Cup, there was a decline in sexual services offered (see Delva et al 2011), ${ }^{10}$ and in South Africa not one single case of human trafficking was reported over this period. This was largely ignored by the South African media. Few reports in the months following the World Cup reported on the lack of human trafficking and the media focus declined substantially. 


\section{Conclusion}

Moral panic around international sporting events is driven by media hypes. The predominant interpretation of human trafficking for sexual exploitation is reinforced and perpetuated through the vehicle of the media. The phantom figure of 40000 trafficked women was the result of a congruence of ideas and beliefs that international sporting events result in an increased demand for sex which is, in turn, provided for through the enslavement and transport of women and children into the host state. The media hype and accompanying moral panic became firmly cemented in both the public consciousness and the dominant discourse. In the South African context there was the superimposition of the dominant international discourse onto the domestic discourse in relation to the 2010 World Cup.

Blanket statements about prostitution and the exploitation of women are propaganda from a political agenda which seeks to control the way people think and behave. The situations which the anti-traffickers rail against, insofar as they do exist, are a result of economic, political and gender inequalities which should be our central cause for concern. The vast range of sex industries and contexts requires an understanding of diversity and difference and a realisation that prohibition and unitary 'moral values' are part of the problem, not the solution (Murray 1998: 64).

The imposition of an international discourse on human trafficking in the South African context is most readily seen in the resurrection of the belief that 40 000 women and girls would be trafficked ahead of the 2010 World Cup. Articles reiterating the assertions of the dominant discourse, warning of the horrors of sex trafficking to come, became part and parcel of the domestic discourse. Sensationalist articles fed on the fears of the public and resulted in an increased sense of moral panic. Similar variants have been witnessed since in the media hype ahead of the 2010 Vancouver Winter Olympics (see Perrin 2007), the United States 2011 Super Bowl (see Kotz 2011) and the 2012 Olympic Games (see Inside the Games 2009; Lyonnais 2012). This demonstrates that media hypes and moral panics are intimately intertwined, self-perpetuating and tenacious. The fixation on the sensationalist side of human trafficking and the perpetuation of false statistics might highlight the cause of human trafficking, but the problem is not addressed. 


\section{Endnotes}

1. STOP was primarily responsible for the estimation and dissemination of figures on human trafficking for the World Cup. These figures are 100000 prostituted women and girls that would be trafficked into and around South Africa. See also Hamman (2011).

2. African Christian Democratic Party MP and Chief Whip Cheryllyn Dudley first linked potential trafficking in South Africa with the fear of 40000 prostitutes who it was believed would be trafficked to Germany for the previous World Cup (Citizen, $6 / 5 / 2006)$.

3. For a critical review of the HRSC report, see Gould, Richter, and Palmery (2010).

4. In reality it was a report by the IOM which refuted the notion that 40000 women were trafficked in Germany during this period. Their research showed that only five women had been trafficked for such purposes during the World Cup.

5. Syndicates were linked to human trafficking in 15 newspaper articles over the period 2006-2010.

6. It was uneventful in the sense that there were only five cases reported.

7. International Migration Organisation, International Labour Organisation and United Nations Organisation on Drugs and Crime.

8. Circa 400000.

9. There is no evidence that can actually support this assertion that preventative measures were the reason why there were no reported cases of human trafficking or forced prostitution during the 2010 FIFA World Cup. It can only be inferred.

10. It was suggested that the global economic downturn did not factor into this lack of demand. Rather international sporting events are becoming more and more family affairs. No longer are they the realm of the rowdy male fans as popular culture and the media would have us believe.

\section{Bibliography}

Barbeau, N (2010), "No need to panic over child trafficking: police", Daily News, 31 May. Bowman, C (2010), "Human trafficking: Beware the little children", Sunday Tribune, 21 March.

Cape Argus (2008), "Warning on child trafficking in 2010", 10 December. Cape

Argus (2009), "Warning on 2010 sex trafficking", 26 October.

Cape Times (2009), "100 000 people could be trafficked into country for 2010", 6

November.

Citizen (2006), "Flesh trade fear for World Cup",6 May. Daily

Dispatch (2010), "15 Minutes with...", 24 May. 
Daily News (2009), "2010 exploitation: Human traffickers ready for World Cup", 19 February.

Daily News (2010), "Human trafficking red alert: Women, children under threat as World Cup sees prostitution demand rocket", 28 March.

Delva, W, Richter, M, De Koker, P, Chersich, M and M Temmerman (2011), "Sex Work during the 2010 FIFA World Cup: Results from a Three-Wave Cross-Sectional Survey", PLoS ONE, Vol 6, No12, e28363, pp. 1-4.

Evans, S (2010), "You have been warned", Diamond Fields Advertiser, 1 June.

Gould, C and M Richter (2010), "The Need for Evidence to Assess Concerns about Human Trafficking During the 2010 World Cup", ISS Today: Institute for Security Studies, 23 March.

Gould, C, Richter, M and I Palmery (2010), "Of Nigerians, albinos, satanists and anecdotes: A critical review of the HSRC report on human trafficking", SA Crime Quarterly, Vol 32, June, pp 37-46.

Hamman, M (2010), Visual Stories of Human Trafficking's Victims. (Available at: http://www.nieman.harvard.edu/reports/article/102519/Visual-Stories-ofHumanTraffickings-Victims.aspx.)

Hamman, M (2011), A tangled web: Human trafficking, child protection and the media. Fletcher, L (ed), Media Monitoring Africa.

Hennig, J, Craggs, S, Larson, F and F Laczko (2006), Trafficking in Human Beings and the 2006 World Cup in Germany. IOM Migration Research Series: IOM.

Human Sciences Research Council (2010), Tsireledzani: understanding the dimensions of human trafficking in Southern Africa. Research Report: HSRC.

Inside the Games (2009), "London 2012 will lead to more sex trafficking admits Minister", 30 September. (Available at: http://www.insidethegames.biz/ olympics/summerolympics/2012/7269-london-2012-will-lead-to-more-sextrafficking-admits-minister.) International Organization for Migration (2007), Trafficking in human beings and the 2006 World Cup in Germany. IOM Migration Research Series: IOM.

Kotz, P (2011), "Super Bowl prostitution: 100,000 hookers didn't show, but America's latest political scam did", Dalas Observer, 3 March.

Langanparsad, M (2010), "Human trafficking red alert: Women, children under threat as World Cup see prostitution demand rocket", Sunday Times, 28 March.

Lyonnais, S (2012), "Business Of Sex: Olympics and Sex Trafficking", Toronto Standard, 26 July. 
Molo Songololo (2008), Rapid assessment of the impact of 2010 FIFA World Cup on the abuse, exploitation and trafficking of children. Cape Town: UNICEF.

Murray, A J (1998), "Debt-Bondage and Trafficking: Don't Believe the Hype", in Kempadoo, Kand K Doezema (eds), Global Sex Workers: Rights, Resistance and Redefinition. New York: Routledge.

Naidoo, Y and S Kretzman (2008), "Child trafficking on the rise in SA", City Press, 23 November.

Perrin, B (2007), Faster, Higher, Stronger: Preventing Human Trafficking at the 2010 Olympics. Future Group. (Available at: http://papers.ssrn.com/sol3/ papers.cfm?abstract_id=1578564.)

Pillay, K (2010), "Be particularly alert to child trafficking", Pretoria News, 15 June.

Richter, M L, Chersich, M F, Scorgie, F, Lutchers, S, Temmerman, M and R Steen (2010), "Sex Work and the 2010 FIFA World Cup: time for public health imperatives to prevail", Globalization and Health, Vol 6, February, pp 1-6.

SERVAMUS: Safety and Security Magazine, (2010), 1 May.

South African Catholic Bishops Conference (2010). (Available at: http://www.sacbc. org.za/Site/index.php?option=com content\&task=view\&id=286\&ltemid=111.)

Sowetan (2009), "Beware of 2010 'sex tourists': Warning on child abuse", 26 October.

Stander, Y and S de Jager (2010), "Child trafficking expected to soar in final holiday before World Cup", Weekend Post, 3 April.

Sunday Independent (2007), "Human trafficking casts shadow over 2010", 23 September.

Sunday Times (2010), "Warning on 2010 sex trafficking 'Human trafficking red alert': Women, children under threat as World Cup sees prostitution demand rocket", 28 March.

The Weekender (2008), "Human trafficking may escalate ahead of 2010 World Cup report", 8 November.

United Nations High Commission for Refugees (2008). (Available at: http://www. unhcr.org/refworld/country , USDOS,,ZAF,456d621e2,484f9a3c3d,0.html.)

United States State Department (2009), Trafficking in Persons Report. (Available at: http://www.state.gov/g/tip/rls/tiprpt/2009/123139.htm.)

United States Department of State (2010), Trafficking in Persons Report. (Available at: http://www.state.gov/g/tip/rls/tiprpt/2010.)

Vasterman, PLM (2005), "Media-Hype:Self-Reinforcing News Waves, Journalistic Standards and the Construction of Social Problems", European Journal of Communication, Vol 20, No 4, pp 508-530.

Weekend Post (2010), "Child trafficking expected to soar in final holiday before World Cup. High Alert: Experts call for exceptional vigilance as syndicates hunt for kids to prostitute", 3 April. 
Witness (2010), "The Dark side of the World Cup", 10 March. 